Environmental Biology of Fishes Vol. 12, No. 3, pp. 161-168, 1985

(C) Dr W. Junk Publishers, Dordrecht.

\title{
A possible relationship between aspects of dentition and feeding in the centrarchid and anabantoid fishes
}

\author{
William A. Gosline \\ Museum of Zoology, University of Michigan, Ann Arbor, MI 48109, U.S.A.
}

Keywords: Teleosts, Evolution, Adaptations, Jaw bite, Oral cavity

\section{Synopsis}

Certain components of dentition - teeth on the third basibranchial in the Centrarchidae and on the parasphenoid in the anabantoids (sensu lato) - are very rare elsewhere in higher teleostean fishes. Though these basibranchial and parasphenoid teeth in the two fish groups are on opposite sides of the oral cavity, it is hypothesized that they both developed as adaptations for gripping a particular category of food items, namely strong-clawed, hard-shelled, active animals that, once within the oral cavity, would try to crawl out again. A corollary to this hypothesis is that higher teleosts with extensive dentition in the central part of the oral cavity have a grasping jaw bite, which, unlike a piercing, shearing, or crushing jaw bite, does not necessarily kill the prey that is taken into the oral cavity.

\section{Introduction}

In the course of teleostean evolution there has been a general trend toward the reduction of dentition in the central part of the oral cavity (Nelson 1969). Two freshwater groups of perciform fishes show what seems to be a redevelopment of such dentition, i.e., on the third basibranchial of the Centrarchidae and on the parasphenoid of the anabantoid fishes (sensu lato). This paper attempts to account for these two components of dentition.

Definitions of what are here considered to constitute centrarchid and anabantoid fishes are followed by a discussion of the developments of the two components of dentition under consideration, and a hypothesis is then presented to account for the presence of teeth on these two bones in the centrarchid and anabantoid fishes. A brief discussion of the presumed relationship between dentition in the central part of the mouth cavity in higher teleostean fishes and a grasping jaw bite concludes the paper.

The report is based primarily on morphological information derived from specimens in the University of Michigan fish collections.

\section{The centrarchid and anabantoid fish groups}

Of the two groups under consideration, the Centrarchidae are interpreted in their usually accepted sense (see e.g. Smith \& Bailey 1961). The monophyletic nature of the Centrarchidae is generally accepted except for the dwarf Elassoma which has sometimes been assigned to a separate group. However, Elassoma, without teeth in the central part of the mouth, is only peripherally relevant to the feeding hypothesis suggested below.

The term anabantoids, as used here, comprises a wider variety of fishes than is usually included un- 
der that name. The groups considered here to be anabantoids comprise the Nandidae, Badis, Pristolepis, the Anabantidae of Regan (1909) or Anabantoidei of Liem (1963), Luciocephalus, and the Channidae (Ophiocephalidae auctorum). In the past the taxonomic treatment of this highly diverse group has varied considerably. Up to now the Nandidae, Badis, and Pristolepis have been included among the percoid fishes, e.g., by Regan (1913). The other members of the group, with a more or less well-developed air-breathing organ in the upper part of the gill chamber, have often been placed in a separate suborder Labyrinthici, e.g., by Weber $\&$ deBeaufort (1922). Various other taxonomic allocations for members of the labyrinth fishes have been proposed, for example, by Regan (1909) and Berg (1940).

The suggestion of a relationship between all of the members here included in the anabantoids apparently goes back to Gosline (1968, see also 1971, and Nelson 1969). Liem, who has studied almost all of the components of the group intensively, disagrees strongly with this interpretation. Most recently, Liem \& Greenwood (1981, p. 89) state: 'On the basis of functional morphological data presented here, the hypothesis that nandids, pristolepids, channids and even anabantoids are closely related must be rejected.' Since my disagreements with Liem's zoological data are relatively minor, it seems that at least a large part of our divergence in phylogenetic interpretation may stem from a difference in viewpoint. Liem, studying the group from within, notices differences, whereas I, looking at the same forms in relation to other fish groups, see similarities (e.g. in fig 1A-E of Liem \& Greenwood 1981).

The following features are held in common by all or most of the fishes assigned to the anabantoids under the broad interpretation adopted here. Of these, three of the last four features listed (auditory bullae, interrupted lateral line, and reduced number of caudal rays), though distinctive are by no means unique in the anabantoid fishes.

The parasphenoid dentition will be discussed in more detail below. Suffice it to say here that teeth are present on the parasphenoid of Nandus in the Nandidae, Badis, Pristolepis, the anabantoid fam- ilies of Liem (1963), channids, and apparently in some specimens of Luciocephalus (Regan 1909). Though parasphenoid teeth are not infrequently present in lower teleosts, e.g., Elops, they have been recorded elsewhere in acanthopteran teleosts only in some individuals of Polymixia (Patterson 1975).

Nelson (1969) has called attention to the presence of tooth plates on the third hypobranchials of nandids, channids, and Pristolepis. Such tooth plates occur in a limited number of other higher teleosts, e.g., Lates (see below).

The olfactory apparatus is essentially similar in all members of the group examined: Nandus, Badis, Pristolepis, several anabantoids (sensu Liem), and Channa. The olfactory rosette consists of a number of nearly parallel lamellae extending posteriorly from an anterior transverse base (rachis). The number of lamellae varies greatly and is most numerous in Channa (Burne 1909). (The usual teleostean nasal rosette has lamellae extending laterally from either side of a central longitudinal rachis.)

The auditory bulla of the skull is more or less expanded. Liem (1970, p. 147) states that nandid genera other than Nandus do not have such an expansion, but his figures 6 and 9 strongly suggest an enlarged bulla, at least in Polycentrus.

The lateral line of the body, if present, is usually either interrupted or jogs. The nasal bone is strongly developed and frequently expanded. It is firmly attached to the skull posteriorly and overlaps the maxillary anteriorly. In forms with extensive premaxillary protrusion, the nasal bone replaces the palatine as a fulcrum for maxillary rotation. The replacement is complete in Luciocephalus (Liem 1967a), incomplete in nandids (Liem 1970).

The branched caudal fin rays are reduced in number from the usual perciform count of 15 . The number of branched rays seems to be somewhat variable, at least in Badis (11 to 13 in five specimens). In individuals of other genera examined: Nandus, Pristolepis, Channa, and the anabantoids (sensu Liem 1963) Ctenopoma, Trichopsis, and Trichogaster, the number of branched caudal rays is 12,13 , or 14 .

Finally, there is the matter of habitat and dis- 
tribution. All of these are freshwater fishes with a center of distribution in southeastern Asia. Liem (1970) objecting to such a statement for nandids (Gosline 1968) pointed out correctly that there are two nandid genera in South America and two in Africa, but only one in southeastern Asia. However, Liem's own postulate of the southeast Asian Nandus as the most generalized member of the family should, I think, be taken into account here.

\section{Teleostean dentition}

Throughout teleostean history there has been repeated specialization in dentition. However, in lower teleosts, e.g., osteoglossids or Elops (Nybelin 1968), there is a general tendency for the whole oral cavity to be lined with teeth. These teeth may be directly embedded in bone, as in the jaws, or on more or less independent toothed plates (Nelson 1969). In the course of teleostean evolution there has been a trend toward specialization of the jaws at the front of the oral cavity and of pharyngeal 'jaws' at the back, with a concomitant diminution of dentition in the central part of the oral cavity. These changes are associated with increased precision in the seizure of food items.
The concern here is with the trend toward reduction of dentition in the central part of the mouth, for it is a reversal of this trend that seems to have occurred in the basal centrarchid and anabantoid stocks. Such a reversal has occurred in various other perciform groups (see Nelson 1969, also the figure of the dentition of Toxotes in Smith 1945), but it has progressed considerably farther in centrarchids and anabantoids than elsewhere. In the basal members of the Centrarchidae (Fig. 1A, B) and in Nandus (Fig. 1C, D) of the anabantoid series there is not only an extensive dental coverage of the central part of the mouth, but teeth are implanted in the third basibranchial of basal centrarchids and in the parasphenoid of Nandus (and most other anabantoids). Teeth on the third basibranchial and on the parasphenoid are very rare elsewhere among higher teleosts. These two sets of teeth are discussed separately below.

\section{Basibranchial dentition in the Centrarchidae}

Basibranchial dentition in teleosts has been surveyed by Nelson (1969). Though tooth plates in the basibranchial area are frequent and variable, Nelson records teeth directly implanted in the third basibranchial only from ophidioids, atherinids, and
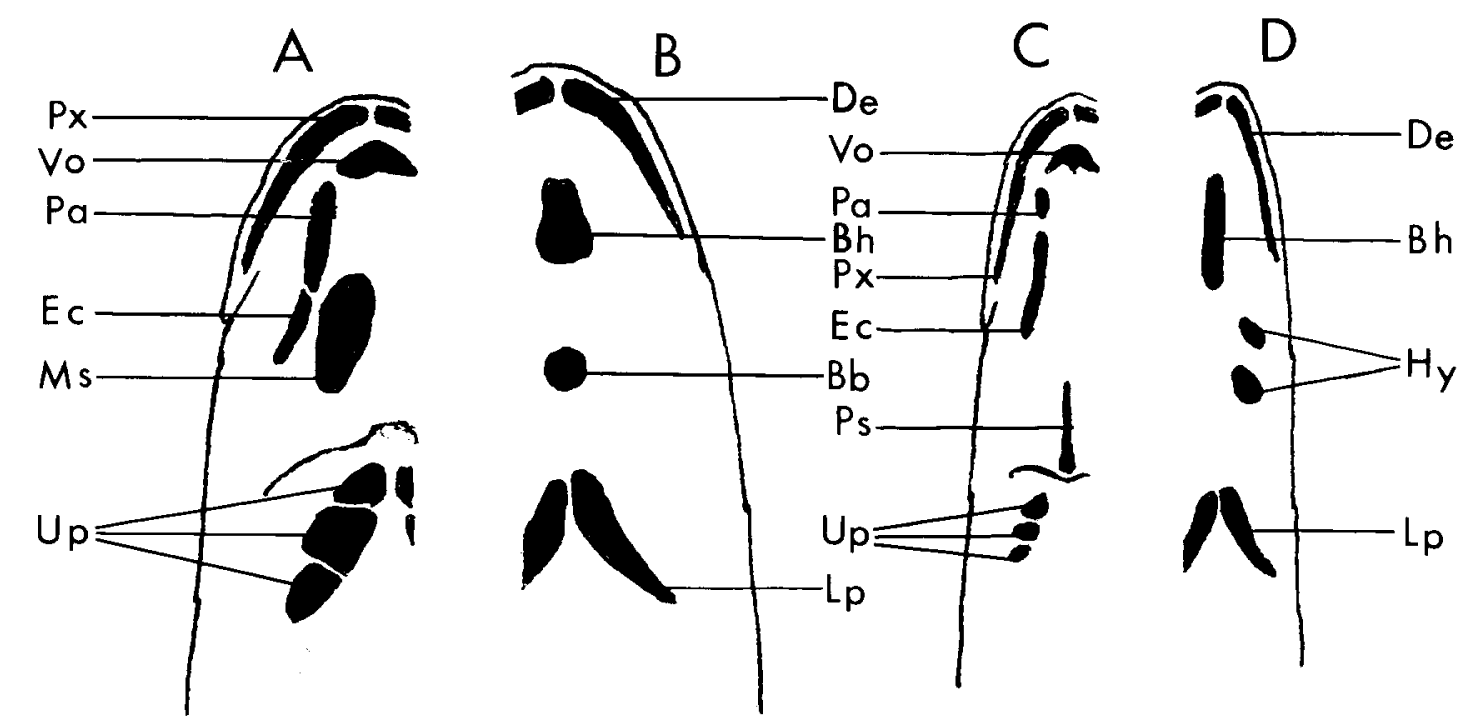

Fig. 1. Diagrams of the dental surfaces of the mouth of Ambloplites rupestris, (A) upper half, and (B) lower half; and Nandus nebulosus, (C) upper half, and (D) lower half. The smaller tooth plates on the gill arches are not shown (Bb-third basibranchial, Bh-basihyal. De-dentary, Ec-ectopterygoid, Hh-enlarged tooth plates on the bases of the second and third hypobranchials, Lp-lower pharyngeal, Ms-mesopterygoid, Pa-palatine, Ps-parasphenoid, Px-premaxillary, Up-upper pharyngeal, and Vo-vomer) 
centrarchids among higher teleosts. In centrarchids, unlike those ophidioids and atherinids with teeth on the third basibranchial, these teeth form an isolated patch or pair of patches about half way between the dentition on the tongue in front and that of the lower pharyngeals posteriorly (Fig. 1B). Furthermore, these basibranchial teeth seem to be a basal feature in the Centrarchidae, for they occur in at least some members of every genus except for the specialized Elassoma. Aside from Elassoma, basibranchial teeth are absent from the species of Lepomis other than L. gulosus and L. cyanellus and in one species of Micropterus, namely M. salmoides.

As to the source of the basibranchial dentition in centrarchids, Nelson (1969, p. 502, footnote 1) noted the possibility of a secondary redevelopment but preferred the hypothesis that it is directly inherited from the basibranchial dentition of lower teleosts. In my view, the basibranchial teeth of centrarchids evolved as a secondary extension from dentition on the third hypobranchial tooth plates. The way in which such an extension may have occurred is suggested in the percoid genus Lates.

In Lates angustifrons (Greenwood 1976, fig. 18) there are toothed plates extending along the lower halves of the gill arches. The largest of these are on the hypobranchials at the bases of the arches, and the largest of all are on the hypobranchials of the third gill arch. In one of two specimens of Lates (Luciolates) stappersi examined by Greenwood (1976, p. 38), he records 'a single, median plate on the third basibranchial and a small plate on each hypobranchial of that arch.' In a Michigan collection of the same species (UMMZ 199901) there is a tooth plate on each third hypobranchial immediately preceded by a separate, longer plate extending forward along each side of the third basibranchial. This pair of tooth plates along the third basibranchial is separated from one another by a narrow median interspace and is more firmly attached to the underlying bone than are the hypobranchial plates just behind. The conditions just described for at least some specimens of Lates stap. persi closely approach those of such a centrarchid as Micropterus dolomieui.

An encroachment of the third hypobranchial tooth plates on to the third basibranchial also occurs in two percichthyid genera. In Siniperca which, along with Coreoperca, Jordan \& Snyder (1901) postulated as ancestral to the Centrarchidae, the encroachment is only moderately developed. However, in Morone the different species show the same complete transition as in Lates from forms with small, normal hypobranchial tooth plates to forms with a central tooth patch on the third basibranchial (personal observations).

The main difference between the third basibranchial teeth of centrarchids and those of Lates or Morone seems to be the direction of evolution within these groups. Lates and Morone each seem to have evolved their basibranchial teeth from the more normal type of percoid dentition, whereas the centrarchids appear to have started with firmly embedded basibranchial teeth which have sometimes been secondarily lost. (With regard to the hypothesis to be presented below, it is unfortunate that the food habits are unknown for the species of Lates, L. stappersi, and of Morone, M. punctata, with the most highly developed basibranchial dentition.)

\section{Parasphenoid dentition in anabantoid fishes}

The source of the parasphenoid teeth in anabantoid fishes is not clear and has elicited considerable speculation. As already noted, the only other record of parasphenoid teeth in acanthopterans is that for some of the specimens of the beryciform genus Polymixia examined by Patterson (1975). Many of the beryciform genera have an unusually extensive, granular dentition lining the oral cavity (see e.g. Patterson 1964). In Polymixia there are teeth on the following bones; premaxillaries, dentaries, vomer, palatines, ectopterygoids, mesopterygoids, and lower pharyngeals, as well as on the parasphenoid of some specimens. In addition, granular dentition is present on various tooth plates, notably on the upper pharyngeals, glossohyal, and basibranchials, but also on the base of the gill arches. Aside from the upper pharyngeals, these tooth plates seem to be variable in size and position. For example, those on the basibranchials vary considerably from fish to fish (see Nelson 1969, pl. 
87 and fig. 6C; also Zehren 1979, fig. 9). Thus, in Polymixia the potentiality for the development of teeth over the surfaces of the oral cavity seems to be great, but variably expressed. In my opinion the parasphenoid teeth of Nandus seem most satisfactorily explained as a similar spread of dentitional potentialities, for Nandus, like Polymixia, has an oral cavity with extensive dental coverage (Fig. 1C, D).

The interpretation of anabantoid relationships presented earlier in the paper includes the supposition that their parasphenoid teeth have evolved only once in the anabantoid stock. This hypothesis is here expanded to the postulate that the original expression of parasphenoid teeth in anabantoids is most closely approximated among modern forms by the parasphenoid dentition of Nandus and has become specialized in various ways, or lost, by other anabantoids (see Liem \& Greenwood 1981 for a different interpretation). The range of these modifications greatly exceeds that of the basibranchial dentition of centrarchids and has led not only to morphological modifications but also to changes in the presumably original grasping function of the parasphenoid teeth of Nandus. Pristolepis, at one extreme, has molariform, probably crushing parasphenoid teeth, whereas in the anabantids at the other, the parasphenoid teeth have become functionally incorporated into the pharyngeal bite (Liem \& Greenwood 1981).

The thesis developed up to this point may be summarized as follows. Dentition has been redeveloped in the central area of the oral cavity by two freshwater perciform groups. This dentition, on the third basibranchial in centrarchids and on the parasphenoid of anabantoids (sensu lato), has evolved in the ancestral stocks of the two groups and has been subsequently lost in some members of each. The parasphenoid teeth of anabantoids, represented in generalized form in Nandus, has also undergone specialization in two different directions within the anabantoids.

\section{A feeding hypothesis}

In the following paragraphs it is proposed that the redevelopment of specialized dentition in the central area of the mouth of the two perciform groups under discussion is an adaptation for the manipulation of a particular category of food items. The items in this category have the following hypothetical characteristics. They are moderate-sized animals that are eaten whole by the fish; they are sufficiently hard-shelled not to be crushed and killed during seizure by the fish jaws; and they are strong-clawed, active animals that, once in the oral cavity, would try to creep out again, probably by way of the gill openings. Examples of animals in this category are the larger crustaceans, e.g. crayfish; some larval insects, e.g. dragonfly nymphs; and some adult insects, e.g. beetles. Presumably the dentition in the central part of the mouth in most centrarchids and in Nandus provides a firmer grasp in this area and aids in preventing such animals from escaping or becoming lodged between the gill arches. (Just how such teeth in the central part of the mouth actually operate during feeding is unknown. Presumably they would hold recalcitrant prey until an additional backward flow of water can be developed by the fish.)

Circumstantial evidence derivable from records of feeding in the fishes under discussion seems to support the hypothesis but presents serious problems. First, there is the expected difficulty that these perciform fishes with specialized dentition in the central part of the mouth also eat other categories of food, and that many other fishes without such dentition successfully eat 'creepy-crawly' items. Second, there are difficulties with the records of natural feeding habits. Those for anabantoids appear to be scattered and mostly confined to incidental comments. The food of centrarchids has been extensively studied (many of the references are included in Carlander 1977, and Scott \& Crossman 1973), but a large component of the investigations is based on stomach contents of centrarchids from non-natural areas, e.g. impoundments. Some of the records of food from the stomachs of various centrarchids from more or less natural areas are given in Table 1.

One line of circumstantial evidence bearing on the hypothesis will be briefly followed here, namely the relationship between food and the pre- 
Table 1. Food of some centrarchid fishes. Centrarchids are all quite opportunistic in their feeding, and the following selected records may not be entirely representative. They are for stomach contents of adults from native, more or less natural areas. + indicates that basibranchial teeth are present, $\bigcirc$ that they are absent.

\begin{tabular}{|c|c|c|}
\hline & $\begin{array}{l}\text { Basibranchial } \\
\text { teeth }\end{array}$ & Food \\
\hline \multicolumn{3}{|l|}{ Centrarchinac } \\
\hline Archoplites interruptus & + & No data on fish in their native area \\
\hline Centrarchus macropterus & + & $\begin{array}{l}\text { Hemipterans, mainly Corixidae, predominant in the diet (Flemer \& } \\
\text { Woolcott 1966) }\end{array}$ \\
\hline Pomoxis nigromaculatus & + & Mosquito larvae. Cladocera, fish young, Copepoda (Keast \& Webb 1966) \\
\hline Ambloplites rupestris & + & Predominantly crayfish (Keast 1977 ) \\
\hline $\begin{array}{l}\text { Acantharchus pomotis } \\
\text { Lcpominae }\end{array}$ & + & No data \\
\hline Enneacanthus gloriosus & + & Chironomid and caddisfly larvae (Schwartz 1961) \\
\hline Micropterus dolomieui & + & $\begin{array}{l}\text { 'Where crayfish are abundant they frequently comprise over two-thirds of } \\
\text { the food' (Carlander 1977) }\end{array}$ \\
\hline Micropterus salmoides & 0 & Predominantly piscivorous, with crayfish secondary (Keast \& Webb 1966) \\
\hline Lepomis gulosus & + & Crayfish an important component (Flemer \& Woolcott 1966) \\
\hline Lepomis cyanellus & + & Terrestrial arthropods, followed by crayfish and amphipods (Minckley 1963) \\
\hline Lepomis macrochirus & 0 & 'A general array of small-bodied invertebrates' (Werner et al. 1977) \\
\hline Lepomis auritus & 0 & Primarily aquatic insects (Davis 1972 ) \\
\hline Lepomis megalotis & 0 & $\begin{array}{l}\text { 'Predominantly large. sediment-dwelling mayfly or odonate nymphs' } \\
\text { (Laughlin \& Werner 1980) }\end{array}$ \\
\hline Lepomis gibbosus & 0 & $\begin{array}{l}\text { 'Mainly gastropod and other prey from vegetation' (Laughlin \& Werner } \\
\text { 1977) }\end{array}$ \\
\hline $\begin{array}{l}\text { Lepomis microlophus } \\
\text { Elassomatinae }\end{array}$ & 0 & Snails predominant (Huish 1957) \\
\hline Elassoma zonatum & 0 & $\begin{array}{l}\text { Copepods, cladocerans, chironomid larvae and pupae (Barney \& Anson } \\
\text { 1920) }\end{array}$ \\
\hline
\end{tabular}

sumably secondary losses and modifications of this central dentition within the two groups of fishes under consideration.

In the family Nandidae, Nandus is the only genus with parasphenoid teeth. Smith (1945, p. 488) states that Nandus feeds on 'fishes, shrimps, and insects'. Among the nandid genera without parasphenoid teeth, Liem (1970, p. 137) notes that 'Monocirrhus and Polycentropsis are highly specialized predators feeding exclusively on other fishes of considerable size'. The anabantoid $\mathrm{Lu}$ ciocephalus is another fish eater (Lauder \& Liem 1981) that has lost or greatly reduced its parasphenoid dentition. Among centrarchids the piscivorous Micropterus salmoides (Table 1), without basibranchial teeth, seems to belong to this same morphological-ecological category; the other species of Micropterus retain basibranchial teeth.

At the other extreme so far as the size of food items is concerned, the anabantoid genus Helostoma is a filter feeder with a highly specialized filtering apparatus but greatly reduced parasphenoid dentition (Liem 1976b).

In the centrarchid genus Lepomis, the basibranchial teeth are retained in only two species, $L$. gulosus and $L$. cyanellus. In these two relatively large-mouthed members of the genus crayfish form an important component of the diet (Table 1, see also Werner 1977, who cites an unpublished thesis by Huish giving coleopterans as the most frequent item in the stomachs of $L$. cyanellus). The species of Lepomis without basibranchial teeth seem to fall into two main feeding categories. The more generalized feeders such as $L$. macrochirus and $L$. auritus appear to feed mostly on aquatic insects of various sorts, whereas $L$. gibbosus and $L$. microlophus, with molariform pharyngeal dentition, have become specialized in the direction of snail 
eating (Table 1, see also Lauder 1983).

As to modifications of the particular types of dentition under consideration here, the anabantoids have evolved much farther than the centrarchids. In one direction Pristolepis, like the centrarchid Lepomis gibbosus, has molariform, presumably crushing dentition, but in Pristolepis the molar teeth are on the parasphenoid above and on an enlarged basihyal tooth plate below (Nelson 1969, Liem \& Greenwood 1981). I have not been able to find a record of the natural feeding habits of Pristolepis. A very different type of parasphenoid modification occurs in Channa and in anabantoids (sensu Liem). Channa stricta is said by Smith (1945, p. 467) to subsist 'on a variety of living creatures, including fish, frogs, snakes, and insects'. Channa has a very powerful bite between the jaws. Though parasphenoid teeth are present, they are relatively far back in the mouth and seem to form an annex to the pharyngeal bite. Anabantoids (sensu Liem) appear to have evolved even farther in combining the parasphenoid dentition with the pharyngeal bite (Liem \& Greenwood 1981).

Though the scattered evidence just presented raises a number of questions, it seems on the whole to favor the 'creepy-crawly' feeding hypothesis proposed here. It does rather clearly indicate that when members of the two groups under consideration specialize in eating very large or very small items they reduce, lose, or modify the dentition in the central part of their mouth cavities.

\section{Teeth in the central part of the mouth and the grasp- ing bite}

A 'grab and gulp' method of eating other animals seems to be the most generalized feeding system in the lower teleostean fishes. In this method, which is used, for example, by Elops (Hobson 1974), the fish simply overswims and closes its mouth on the prey. Where the various types and sizes of prey will be in the mouth cavity when it closes will vary from item to item, but the dentition more or less completely lining the oral cavity will grasp the item wherever it is. Some higher teleosts, e.g. tunas, use this feeding method, but the great majority place more emphasis on seizing or biting the prey between the jaws.
A specialization in the direction of jaw bite has evolved many times in teleostean evolution. However, the whole higher teleostean stock holds in common a type of upper jaw specialization that does not occur elsewhere in vertebrates, namely a premaxillary protrusion system that provides a firm bite with the premaxillaries protruded (Alexander 1967, Gosline 1981). That this type of premaxillary protrusion, at least as first developed, gives a grasping type of jaw bite is indicated by the bands of small teeth associated with it and by its imprecise occlusion.

Though a single fish is often capable of more than one type of bite, at least a partial distinction can be drawn between the simple grasping bite and the numerous more specialized types that pierce, shear, or crush the prey. Prey do not usually pass alive beyond these more specialized types of bite, but they may do so with a grasping bite.

Once in the mouth, living prey apparently cannot be manipulated forward again to between the jaws for mastication, and any further processing of prey takes place behind the jaws, usually by the pharyngeal 'jaws' at the posterior end of the mouth cavity. Between these two sets of jaws, the gill arches and gill openings offer at least potential lateral escape routes.

If, as hypothesized earlier in the paper, the function of dentition in the central part of the mouth cavity in higher teleostean fishes is mainly to prevent the escape of living prey, it should and apparently does follow that the presence of such teeth is associated with a grasping bite. However, the extent to which fishes with a grasping bite will actually have dentition in the center of the mouth seems to depend, at least in part, on the type of food items they grasp, as indicated by the preceding discussion.

\section{Acknowledgments}

I wish to thank George Lauder for his comments on the manuscript and Earl Werner and Wallace Dominey for help with the literature on centrarchid feeding. 


\section{References cited}

Alexander, R. McN. 1967. The functions and mechanisms of the protrusible jaws of some acanthopterygian fish. J. Zool., Lond. 151: 43-64

Barlow, G.W., K.F. Liem \& W. Wickler. 1968. Badidae, a new fish family - behavioural, osteological, and developmental evidence. J. Zool., Lond. 156: 415-447.

Barney, R.L. \& B.J. Anson. 1920. Life history and ecology of Elassoma zonatum. Ecology 1: 241-256.

Berg, L.S. 1940. Classification of fishes, both recent and fossil. Trav. I. Zool. Acad.Sci. de I'URSS 5: 87-517.

Burne, R.H. 1909. The anatomy of the olfactory organ of teleostean fishes. Proc. Zool. Soc. Lond. 1909: 610-663.

Carlander, K.D. 1977. Handbook of freshwater fishery biology. Vol. 2. Iowa State Univ. Press, Ames. 431 pp.

Davis, J.R. 1972. Spawning, fecundity, and food of Lepomis auritus in southeastern North Carolina. Proc. Southeastern Assoc. Game \& Fish Comm. 25: 556-560.

Flemer, D.A. \& W.S. Woolcott. 1966. Food habits and distribution of fishes of Tuckahoe Creek, Virginia, with special reference to the bluegill, Lepomis m. macrochirus Rafinesque. Chesapeake Sci. 7: 75-89.

Gosline, W.A. 1968. The suborders of perciform fishes. Proc. U.S. Nat. Mus. 124: 1-78.

Gosline, W.A. 1971. Functional morphology and classification of teleostean fishes. Univ. Hawaii Press, Honolulu. 208 pp.

Gosline, W.A. 1981. The evolution of the premaxillary protrusion system in some teleostean fish groups. J. Zool., Lond. 193: 11-23.

Greenwood, P.H. 1976. A review of the family Centropomidae (Pisces, Perciformes). Bull. Brit. Mus. (Nat. Hist.), Zool. 29 $1-81$.

Hobson, E.S. 1974. Feeding relationships of teleostean fishes on coral reefs in Kona, Hawaii. U.S. Mar. Fish. Serv. Bull. 72: 915-1031.

Huish, M.T. 1957. Food habits of the Centrarchidae of Lake George, Florida. Proc. Southeastern Assoc. Game \& Fish Comm. 11: 302-312.

Jordan, D.S. \& J.O. Snyder. 1901. A list of fishes collected in Japan by Keinosuke Otake, and by the United States Fish Commission steamer 'Albatross', with descriptions of fourteen new species. Proc. U.S. Nat. Mus. 23: 335-380.

Keast, A. 1977. Mechanisms expanding niche width and minimizing intraspecific competition in two centrarchid fishes. pp. 333-385. In: M.K. Hecht, W.C. Steere \& B. Wallace (ed.) Evolutionary Biology 10, New York.

Keast, A. \& D. Webb. 1966. Mouth and body form relative to feeding ecology in the fish fauna of a small lake, Lake Opinicon, Ontario. J. Fish. Res. Board Can. 23: 1845-1874.

Lauder, G.V. 1983. Neuromuscular patterns and the origin of trophic specialization in fishes. Science 219: 1235-1237.

Lauder, G.V. \& K.F. Liem. 1981. Prey capture by Luciocephalus pulcher: implications for models of jaw protrusion in teleost fishes. Env. Biol. Fish. 6: 257-268.

Laughlin, D.R. \& E.E. Werner. 1980. Resource partitioning in two coexisting sunfish: pumpkinseed (Lepomis gibbosus) and northern longear sunfish (Lepomis megalotis peltastes). Can. J. Fish. Aquat. Sci. 37: 1411-1420.

Liem, K.F. 1963. The comparative osteology and phylogeny of the Anabantoidei (Teleostei, Pisces). Illinois Biol. Mon. 30: $1-149$.

Liem, K.F. 1967a. A morphological study of Luciocephalus pulcher, with notes on gular elements in other recent teleosts. J. Morph. 121: 103-134.

Liem, K.F. 1967b. Functional morphology of the head of the anabantoid fish Helostoma temmincki. J. Morph. 121: 135158.

Liem, K.F. 1970. Comparative functional anatomy of the Nandidae (Pisces: Teleostei). Fieldiana: Zool. 56: 1-166.

Liem, K.F. \& P.H. Greenwood. 1981. A functional approach to the phylogeny of the pharyngognath teleosts. Amer. Zool. 21: 83-101.

Minckley, W.L. 1963. The ecology of a spring stream, Doe Run, Meade County, Kentucky. Wildl. Mon. 11: 1-124.

Nelson, G.J. 1969. Gill arches and the phylogeny of fishes, with notes on the classification of vertebrates. Bull. Amer. Mus Nat. Hist. 141: 475-552.

Nybelin, O. 1968. The dentition in the mouth cavity of Elops. pp. 439-444. In: Nobel Symposium 4: Current Problems of Lower Vertebrate Phylogeny.

Patterson, C. 1964. A review of Mesozoic acanthopterygian Fishes, with special reference to those of the English Chalk. Phil. Trans. Roy. Soc. London, ser. B, 247: 213-482.

Patterson, C. 1975. The braincase of pholidophorid and leptolepid fishes, with a review of the actinopterygian braincase. Phil. Trans. Roy. Soc. London, ser. B, 269: 275-579.

Regan, C.T. 1909. Asiatic fishes of the family Anabantidae. Proc. Zool. Soc. London 1909: 767-787.

Regan, C.T. 1913. The classification of the percoid fishes. Ann. Mag. Nat. Hist., ser. 8, 12: 111-145.

Schwartz, F.J. 1961. Food, growth, and morphology of Enneacanthus chaetodon. Chesapeake Sci. 2: 82-88.

Scott, W.B. \& E.J. Crossman. 1973. Freshwater fishes of Canada. Fish. Res. Board Can. Bull. 184. 966 pp.

Smith, C.L. \& R.M. Bailey. 1961. Evolution of the dorsal-fin supports of percoid fishes. Pap. Michigan Acad. Sci., Arts, \& Let. 46: 345-363.

Smith, H.M. 1945. The fresh-water fishes of Siam, or Thailand. U.S. Nat. Mus. Bull. 188: 1-621.

Weber, M. \& L.F. deBeaufort. 1922. Fishes of the Indo-Australian Archipelago. Vol. IV. E.J. Brill, Leiden. 410 pp.

Werner, E.E. 1977. Species packing and niche complementarity in three sunfishes. Amer. Nat. 111: 553-578.

Werner, E.E., D.J. Hall, D.R. Laughlin, D.J. Wagner, L.A. Wilsmann \& F.C. Funk. 1977. Habitat partitioning in a freshwater fish community. J. Fish. Res. Board Can. 34: 360-370.

Zehren, S.J. 1979. The comparative osteology and phylogeny of the Beryciformes (Pisces: Teleostei). Evolutionary Mon. 1: $1-389$.

Received 7.11.1983 Accepted 14.2.1984 